MAREK MATEJUN

MARCIN RATAJCZAKI

\title{
Economic and social
}

benefits of socially

responsible actions

towards employees in

agribusiness enterprises

\section{Introduction}

The concept of corporate social responsibility (CSR) assumes that enterprises at the stage of strategy building should voluntarily take into account social interests, environmental protection and relations with all their stakeholders, especially with employees (Żemigała, 2007, p. 99). Thus, this business approach means that responsibility consists in not only meeting all formal and legal requirements by business entities but also in voluntarily undertaking investments in human resources, protection of the natural environment and building positive relations

Prof. Eng. Marek Matejun, University of Lodz, Faculty of Management, Poland, ORCID: 0000-0003-4885-2344.

Marcin Ratajczak, Ph.D., Warsaw University of Life Sciences, Faculty of Economic Sciences,

Poland, with the companyss stakeholders (Ratajczak, Wołoszyn, Stawicka, 2012, pp. 26-38).

The benefits of using the CSR concept are noticed, among others, by the European Commission in its document entitled "Green Paper" that defines social responsibility as an idea in the framework of which companies voluntarily incorporate social and environmental issues into their business

1 Names in the alphabetical order. The contribution of each author to the preparation of the paper is $50 \%$. 
activities and in all relations with their stakeholder groups, especially internal ones (Green Paper, 2001).

In addition, in May 2010, the first international standard of social responsibility called ISO 26000 was adopted during the ISO (International Standard Organization) plenary session in Copenhagen. It presents a description of the seven main CSR areas relating to organizational order, human rights, natural environment, market practices, consumer issues, social involvement and relations with employees. The last area is understood as undertaking various activities with people performing work for a given organization, both within the internal and external structure of the enterprise (Hąbek, Szewczyk, 2010, pp. 36-44).

The aim of the paper is to identify the scope of socially responsible actions towards employees in agribusiness enterprises and to assess their impact on the level of economic and social benefits resulting from the use of the CSR concept in business practice. The empirical research carried out on a sample of 325 micro, small and medium-sized enterprises operating in rural areas of the Mazowieckie Voivodeship served to meet the objective of the paper.

\section{Literature review}

In the modern economy, the implementation of CSR is increasingly becoming a strategic challenge for organizations, and thus moves away from the initial understanding of this concept as an only voluntary consideration of social and ecological aspects in relations with their stakeholders (Buysee, Verbeke, 2003, pp. 453-475). Under the conditions of increasing competition, the nonmaterial value of an organization, the ethics in its actions and the trust of its stakeholders, especially of its own employees, are being emphasized. That is why it is very important to assess which stakeholders are affected by the goals set and development directions adopted by a given company as well as which stakeholders have a key impact on the growth of the quality and value of a given business entity (Carroll, 1974, pp. 75-90).

In recent years, an increasing number of companies from the agribusiness sector in Poland are beginning to implement the principles of the CSR concept. It must be emphasized that agribusiness is a type of economic activity that uses resources possessed by enterprises to produce various types of material goods (food and non-food items) and services (Kapusta, 2012, pp. 37-64). Nowadays, agribusiness is seen as a broad economic activity which includes production and services in the area of manufacturing of means of 
production and providing services necessary for agriculture and processing of agricultural raw materials, sourcing of raw materials in agriculture and forestry, storing and sorting of products created from agricultural raw materials, wholesale, retail, export, import and marketing services (Kapusta, 2012, pp. 123-149).

All of the above-presented activities have an impact on the fact that the use of social responsibility in agribusiness enterprises is becoming increasingly important and also affects the further development of this concept (Garriga, Melé, 2004, pp. 51-68). Today, companies in this industry are expected to act responsibly towards the general public good - that is why sustainable production in these enterprises is very often defined as the manufacturing of products and the provision of services using systems and processes that are safe and healthy for employees, customers and communities, provide adequate remuneration for internal stakeholders, save energy and natural resources, and do not pollute the natural environment (Vogel, 2005).

Especially in the sphere of agribusiness, the social and ecological value of products can become a specific form of product innovation, and thus build a competitive advantage in an increasingly demanding global market. In this respect, it can certainly be said that the principles of social responsibility in agribusiness, such as actions taken for the sake of employees or taking into account environmental needs, are becoming a necessity and everyday practice in these enterprises (Ratajczak, 2016, pp. 337-351).

The implementation of the principles of social responsibility in agribusiness enterprises must be preceded by understanding on the part of employees and owners that the activities conducted only and exclusively for profit often have many negative side effects (Waddock, 2008, pp. 87-107). The values professed and implemented by internal stakeholders of a given enterprise are very often based on personal beliefs that are brought into the organization, influencing the organizational culture, and at the same time drawing from it. A company that declares and abides by internal ethical principles becomes more credible in the eyes of public opinion, and thus builds a positive external image. This image is largely determined by the attitude of its employees and their relationship with the entire market environment of a given agribusiness enterprise (Roome, 2009, pp. 25-34).

Employees are a key asset of any enterprise. Thanks to their knowledge, skills and decisions, a given company operates effectively in the market and achieves its goals. Therefore, a well-structured personnel policy created within the scope of the CSR concept should contribute to the achievement 
of certain economic and social benefits by the company (Sethi, 1979, pp. 5765). The literature assumes that the development of appropriate personnel policy principles in the area of employee performance appraisals, the system of penalties and awards, satisfaction surveys or personal data protection should contribute to greater economic efficiency of the entire enterprise (Martin, 2002, pp. 69-75). It will also allow for stable business operations, avoiding internal misunderstandings and emphasizing the coherence of all activities carried out by a given organization, which in turn should translate into lower operating costs, profit growth and certain social benefits related to improving the image of agribusiness enterprises in their environment (Ratajczak, 2013, pp. 14-19).

\section{Research methodology}

The empirical research carried out in the form of a diagnostic survey (Apanowicz, 2003, pp. 84-86) on a sample of 325 agribusiness enterprises operating in rural areas of the Mazowieckie Voivodeship served to meet the aim of the paper. The study was conducted at the turn of 2016 and 2017. They were financed from funds obtained under the grant for young scientists. The geographical area of research was deliberately chosen taking into account the high level of socio-economic development and competitiveness of the region compared to other regions in Poland (Grodzka, 2017, pp. 187-191). At the same time, this area is characterized by relatively high (though internally diverse) indicators of rural development (Wojewódzka-Wiewiórska, 2015, pp. 123-132). It has the largest share of both plant and animal production as well as the largest share of high conservation value areas. In this region, the specialization of production at the level of farms can be observed, especially in the area of milk and fruit production, which positively affects the economic efficiency of agribusiness enterprises, the development of links between trading partners, the construction of industry technical infrastructure and the diffusion of knowledge (PROW 2014-2020, pp. 14-30).

The computer-assisted survey was selected as the research technique and an electronic questionnaire addressed to the surveyed entities was the research tool. Data on the surveyed companies were purchased from the Central Statistical Office and the criterion for the breakdown into micro, small and mediumsized entities was the number of employees and the activity section (Polish Classification of Activities - PKD). The invitation to participate in the study was sent to all agribusiness entities operating in the Mazowieckie Voivodeship 
(almost 2,000 companies in total) and, as a result, 325 fully and correctly filled out questionnaires were received.

The analyzed sample includes enterprises of various sizes, measured by the declared level of employment, including: 51\% micro enterprises (0-9 employees), $29 \%$ small enterprises (10-49 employees) and 20\% medium-sized enterprises (50249 employees). The organizational forms were dominated by natural persons conducting business activity (38\%), civil partnerships (28\%) and partnerships (24\%). The industry classification was made taking into account the specificity of agribusiness activity (Knecht, Jankowska, Popiołek, 2009, p. 93) distinguishing: $43 \%$ entities operating in the field of industrial processing, 30\% in agriculture, $20 \%$ in the sphere of trade, and $7 \%$ in the area of transport services. In spatial terms, most of the companies surveyed were located in rural areas near large urban agglomerations, especially in the vicinity of Warsaw, Radom, Skierniewice, Ciechanów or Płock.

Measurements of phenomena considered in the paper were made on the basis of opinions of the respondents, i.e. owners of the surveyed entities. The respondents were mainly men (67\%), mostly persons up to 45 years old $(78 \%)$, with secondary education (27\%) or university education (59\%).

On the basis of the collected empirical material, statistical analysis was carried out in which the following quantitative methods were used (Swift, Piff, 2014): measures of position, analysis of count data, Spearman's $\left(\mathrm{r}_{\mathrm{s}}\right)$ correlation coefficient and its significance test as a measure of interdependence of phenomena, and multiple linear regression analysis. To assess the strength of interdependence of the studied phenomena, the approach adapted to the specificity of social opinion survey was used, adopting the following levels of dependence as the threshold values of the linear correlation coefficient: 0.1 - weak; 0.3 - medium; 0.5 - strong (Finch, Immekus, French, 2016, p. 110).

\section{Research results}

In the first part of the study, the scope of implementation of selected socially responsible actions towards employees in the surveyed companies was analyzed and assessed. The results based on the respondents' declarations indicate a significant scope of such activities. The companies surveyed conduct, among others, employee satisfaction surveys as well as regular employee performance appraisals, which are often the basis for further personal and professional development of employees. They offer employees various economic incentives, mainly flexible forms of employment and covering the costs of additional medical care. A drawback is a relatively small 
scope of the implementation of formal and comprehensive solutions that ensure the protection of personal data and privacy of employees.

The results indicate that the scope of implementation of socially responsible actions towards employees grows moderately as the size of the surveyed companies increases. This mainly applies to the formalization of personnel policy, $\mathrm{r}_{\mathrm{s}}(\mathrm{N}=325)=0.41, \mathrm{p}<0.01$, the regularity of employee evaluations, $\mathrm{r}_{\mathrm{s}}(\mathrm{N}=325)$ $=0.35, \mathrm{p}<0.01$, and the cyclical nature of job satisfaction surveys conducted among employees, $\mathrm{r}_{\mathrm{s}}(\mathrm{N}=325)=0.34, \mathrm{p}<0.01$. Along with an increase in their size, companies also offer a significantly larger range of socially responsible economic incentives, $r_{s}(N=325)=0.21, p<0.01$. Detailed results of the study are presented in table 1.

Table 1. The scope of socially responsible actions towards employees in the surveyed companies

\begin{tabular}{|c|c|c|c|c|}
\hline \multirow{2}{*}{$\begin{array}{l}\text { Socially responsible actions } \\
\text { towards employees }\end{array}$} & \multirow{2}{*}{$\begin{array}{l}\text { Total in } \\
\text { the sample }\end{array}$} & \multicolumn{3}{|c|}{ In companies: } \\
\hline & & micro & small & medium \\
\hline \multicolumn{5}{|c|}{ Personnel policy } \\
\hline No personnel policy & $22 \%$ & $32 \%$ & $16 \%$ & $5 \%$ \\
\hline General policy without formulated objectives & $41 \%$ & $48 \%$ & $37 \%$ & $26 \%$ \\
\hline $\begin{array}{l}\text { Policy with documented, measurable and moni- } \\
\text { tored objectives }\end{array}$ & $38 \%$ & $20 \%$ & $47 \%$ & $70 \%$ \\
\hline \multicolumn{5}{|c|}{ Regular employee performance appraisals } \\
\hline Not used & $21 \%$ & $30 \%$ & $15 \%$ & $6 \%$ \\
\hline $\begin{array}{l}\text { Used without any correlation with professional } \\
\text { development planning }\end{array}$ & $33 \%$ & $38 \%$ & $33 \%$ & $18 \%$ \\
\hline $\begin{array}{l}\text { Used as an important element of planning further } \\
\text { professional development of employees }\end{array}$ & $47 \%$ & $32 \%$ & $52 \%$ & $76 \%$ \\
\hline
\end{tabular}

\begin{tabular}{l|c|c|c|c}
\hline \multicolumn{2}{c}{ Employee satisfaction surveys } & \multicolumn{3}{c}{} \\
\hline No surveys & $22 \%$ & $34 \%$ & $13 \%$ & $5 \%$ \\
\hline Conducted sporadically & $26 \%$ & $28 \%$ & $28 \%$ & $20 \%$ \\
\hline Conducted cyclically & $52 \%$ & $38 \%$ & $60 \%$ & $76 \%$ \\
\hline
\end{tabular}


Data protection and protection of employee privacy

\begin{tabular}{l|c|c|c|c}
\hline No data protection policy & $35 \%$ & $48 \%$ & $26 \%$ & $18 \%$ \\
\hline Procedures apply only to selected data & $29 \%$ & $26 \%$ & $35 \%$ & $29 \%$ \\
\hline $\begin{array}{l}\text { Protection in the form of formal policies and pro- } \\
\text { cedures }\end{array}$ & $35 \%$ & $26 \%$ & $39 \%$ & $53 \%$ \\
\hline
\end{tabular}

Socially responsible economic incentives

\begin{tabular}{|c|c|c|c|c|}
\hline The average number of incentives, including: & 2.3 & 2.2 & 2.4 & 2.6 \\
\hline Additional medical care for all employees & $57 \%$ & $54 \%$ & $54 \%$ & $68 \%$ \\
\hline Additional medical care for management & $15 \%$ & $15 \%$ & $16 \%$ & $12 \%$ \\
\hline Employee pension scheme & $38 \%$ & $38 \%$ & $44 \%$ & $32 \%$ \\
\hline Flexible forms of employment & $85 \%$ & $85 \%$ & $84 \%$ & $88 \%$ \\
\hline Reimbursement of professional development costs & $39 \%$ & $32 \%$ & $38 \%$ & $58 \%$ \\
\hline
\end{tabular}

Source: own study based on research results

On the basis of the responses provided, a synthetic measure was constructed characterizing the overall level of activity of the surveyed companies in the field of socially responsible actions towards employees. This measure was calculated as the arithmetic mean of the numerical representation of the responses in terms of all the considered components of the CSR concept. In the case of personnel policy, employee performance appraisals, employee satisfaction surveys as well as data protection and protection of employee privacy, an ordinal scale of $1-3$, whose numerical values represent individual categories of responses, was used. Additionally, the number of socially responsible economic incentives used in the company was taken into account. As a result, the variability range of the synthetic measure is within the 0.83.6 range. The Cronbach alpha coefficient was used to assess the reliability of the proposed scale (Cronbach, Shavelson, 2004, pp. 391-418) assuming its acceptable level within the 0.7-0.9 range (Tavakol, Dennick, 2011, pp. 53-55). The obtained result alpha $\mathrm{Cr} .=0.740$ indicates that the respondents' answers ensure adequate statistical cohesion so that they can be considered as a substantive representation of the general activity of the surveyed companies in the field of socially responsible actions towards employees. 
The obtained result indicates that the surveyed companies take actions towards employees in the CSR field at the level of 2.2, which represents an average level of this activity in relation to the adopted scale. Involvement in socially responsible actions grows statistically to a moderate extent as the size of the surveyed entities increases, $r_{s}(N=325)=0.46, p<0.01$, and it is fairly high at 2.6 for medium-sized companies.

In the next part of the research, the respondents' opinions on the scope of benefits resulting from the use of the CSR concept in business practice were assessed. The considerations include (1) economic benefits related to the company's financial performance and factors building its competitive market advantage, as well as (2) social benefits related mainly to the positive image of the company in its environment, in particular among its external stakeholders. To assess these benefits, a 3-point ordinal scale was used in which individual measures expressed the following statements: 1 - no benefits indicated or occurrence of negative effects, 2 - a lack of opinion or a small scope of benefits gained, and 3 - clear occurrence of benefits. In addition, in response no. 3, the respondents could indicate certain types of identified benefits.

The results indicate that in the majority of the surveyed companies there was a clear occurrence of economic (55\%) and social (58\%) benefits derived from the use of the CSR concept, and their scope grows significantly statistically along with the size of the entities, as for medium-sized companies the values are $73 \%$ and $76 \%$ respectively. On the other hand, a lack of benefits in both categories was indicated by $30 \%$ and $32 \%$ of the respondents respectively. Among economic benefits, the respondents indicated primarily lower costs $(89 \%)$ and greater profits (72\%). The CSR activities translated, however, to a lesser extent into higher quality of products and services offered ( $28 \%)$. In the area of social benefits, an increase in trust among external stakeholders $(93 \%)$ and obtaining various types of distinctions and awards that build a positive market image $(64 \%)$ were identified. To a lesser extent, the respondents pointed to an increase in the possibility of obtaining certificates confirming the company's competences $(28 \%)$ and an increased scope of media information on socially responsible actions undertaken by the company (15\%).

The final research task was to determine the direction and strength of the impact of socially responsible actions towards employees on the level of identified benefits. The results indicate a positive relationship between the analyzed phenomena. The overall level of involvement in the CSR activities is strongly related to both economic benefits, $\mathrm{r}_{\mathrm{s}}(\mathrm{N}=325)=0.67, \mathrm{p}<0.01$, and social benefits, $\mathrm{r}_{\mathrm{s}}(\mathrm{N}=325)=0.51, \mathrm{p}<0.01$. In order to more precisely determine the impact of 
individual components of the CSR concept on the level of identified benefits, multiple regression analysis was carried out. As the dependent variables, the assessments of economic (model 1) and social (model 2) benefits were adopted. First, the impact of control variables (models 1a and 2a), which included the size of the surveyed enterprises and the demographic characteristics of the respondents, was considered. Then, the main predictors, i.e. the analyzed components of the CSR concept, were added to models $1 \mathrm{~b}$ and $2 \mathrm{~b}$. The results of the analysis are presented in table 2.

Table 2. Analysis of the impact of the CSR actions towards employees on the level of economic and social benefits

\begin{tabular}{l|c|c|c|c|c}
\hline \multicolumn{1}{c|}{ Variable } & Model 1a & Model 1b & Model 2a & Model 2b \\
\hline Dependent variable: & \multicolumn{2}{|c|}{ Economic benefits } & \multicolumn{2}{|c}{ Social benefits } \\
\hline Company size & $0.11^{*}$ & $-0.20^{* *}$ & 0.09 & $-0.14^{*}$ \\
\hline Respondent's gender & 0.06 & $0.10^{*}$ & -0.11 & -0.08 \\
\hline Respondent's age & -0.13 & 0.04 & -0.03 & 0.11 \\
\hline Respondent's education & 0.01 & -0.01 & 0.08 & 0.05 \\
\hline Personnel policy & & $0.10^{*}$ & & $0.14^{*}$ \\
\hline Employee performance appraisals & & $0.18^{* *}$ & & 0.00 \\
\hline Employee satisfaction surveys & & $0.35^{* *}$ & & $0.37^{* *}$ \\
\hline $\begin{array}{l}\text { Data protection and protection of employee } \\
\text { privacy }\end{array}$ & & $0.25^{* *}$ & & $0.22^{* *}$ \\
\hline Scope of application of economic incentives & & $0.12^{* *}$ & & 0.01 \\
\hline Observations & 325 & 325 & 325 & 325 \\
\hline $\mathrm{R}^{2} / \mathrm{R}^{2}$ corrected & $0.03 / 0.02$ & $0.48 / 0.47$ & $0.04 / 0.02$ & $0.29 / 0.27$ \\
\hline F-stat & $2.57^{*}$ & $32.71^{* *}$ & $3.00^{*}$ & $14.30^{* *}$ \\
\hline
\end{tabular}

Multiple linear regression analysis. In order to analyze the direction and relative strength of the influence that the predictors have on the dependent variable, the table presents the values of standardized coefficients. ${ }^{*}$ significant at 0.05 ; ${ }^{* *}$ significant at 0.01 .

Source: own study based on research results 
The obtained results for models $1 \mathrm{a}$ and $2 \mathrm{a}$ indicate a lack of significant impact of control variables on the level of identified benefits. An exception is the size of the company that has a positive impact on the scope of economic benefits, which is associated with the generally greater economic and financial potential of small and medium-sized enterprises in relation to micro-enterprises. The introduction of the set of the main predictors into the models changes the interpretation of results which indicate that the majority of the CSR actions towards employees significantly determine the level of identified benefits. Both economic and social effects are to the greatest extent stimulated by cyclically conducted employee satisfaction surveys as well as the implementation of formal and comprehensive procedures guaranteeing the privacy of employees. In order to ensure economic benefits, it is also important (though to a lesser degree) to introduce regular employee performance evaluations and to increase the scope of using additional economic incentives. The implementation of an appropriate personnel policy, which at the same time constitutes the third important component impacting the level of social benefits, has the relatively smallest influence in this case.

It is worth noting that after the introduction of the main predictors, the direction of the impact of the company's size on the level of identified benefits has changed. This means that the use of socially responsible actions towards employees has stronger and special significance in smaller companies, producing an increase in the level of positive effects. This is due to, among others, the specific atmosphere of work in the smallest entities, based on informal contacts, direct and strong integration with the company, enhanced cooperation between employees and high independence of the staff (Lachiewicz, Matejun, 2012, pp. 16-17). The results indicate that under these conditions, the implementation of socially responsible actions towards employees allows companies to achieve additional economic and social benefits, at the same time increasing the advantage of the sociocultural system of smaller companies with respect to solutions applied in larger business entities.

The fit of models $1 \mathrm{a}$ and $2 \mathrm{a}$, as measured by the determination coefficient $\mathrm{R}^{2}$, indicates a very small, insufficient scope of explanation of the variability of the dependent variables provided by the adopted control variables. The introduction into models $1 \mathrm{~b}$ and $2 \mathrm{~b}$ of the main predictors significantly increases the quality of the fit, which in the case of economic benefits is approx. $50 \%$, while in relation to social benefits amounts to approx. $30 \%$. In view of the complexity of the constructs considered in this study as well as varied interpretations and natural differences in social assessments made by the respondents, it is possible to assess the fit of the considered models as sufficient. 


\section{Conclusions and implications}

Socially responsible actions towards employees constitute an important theoretical component and a manifestation of the implementation of the CSR concept in business practice. They also play an important role in agribusiness enterprises, mainly due to the very high significance of goods and services offered on the market by these economic entities, for which, to some extent, internal stakeholders, i.e. employees of these companies, are responsible.

This is confirmed by the presented research results which indicate that the involvement of the surveyed companies in socially responsible actions towards employees is a source of specific economic and social benefits. To the largest extent, these actions translate into financial performance in the form of reducing operating costs and increasing company profits as well as into building a positive image of the company in the environment by increasing trust among its external stakeholders and gaining prestigious awards and distinctions confirming the company's success. The conducted research allows us to formulate further managerial implications, useful especially for owners and managers of agribusiness enterprises:

- obtaining economic benefits requires a greater scope and more comprehensive involvement in actions socially responsible towards employees than in the case of obtaining social benefits,

- increasing the involvement of agribusiness enterprises in actions socially responsible towards employees becomes justified especially in smaller companies, where it translates to a greater extent into certain economic and social benefits.

Considering the results obtained and formulating conclusions based on these findings, the limitations of the conducted research should be taken into account. They mainly result from the use of an inductive study approach (Popper, 2014) and the survey research as the research method (Nardi, 2018, pp. 1-25). Their limitations include, first of all, high subjectivism of respondents' opinions as well as differences in interpretation and individual perception of the issues under consideration. The problem lies also in the declarativeness of the answers provided, as there is no guarantee that the socially responsible actions and benefits analyzed are actually found in the surveyed companies. The methodical limitation is the treatment of ordinal variables as quantitative measures, which determined their use in the applied regression analysis. The consequence of this fact is the inability to forecast quantitative changes in the level of benefits based on the variability of involvement of the surveyed companies in socially 
responsible actions towards employees. The conducted analysis allowed us only to assess the direction and relative strength of the impact of the considered set of predictors on the dependent variables.

The importance of the subject matter for the functioning of agribusiness enterprises indicates the need for further research. The main research problem should be designing more complex measurement scales allowing for deeper and more objective identification and assessment of the scope and effects of using the CSR concept in business practice. In the research process, it is also worth using to a larger extent measures taking into account the specificity of agribusiness as well as introducing an in-depth classification of benefits derived from the use of the CSR concept. In methodological terms, valuable conclusions may be drawn from in-depth case studies focused primarily on the presentation of model solutions (benchmarks) used in the practice of the functioning of agribusiness enterprises.

\section{Summary}

Economic and social benefits of socially responsible actions towards employees in agribusiness enterprises

The aim of the paper is to identify the scope of socially responsible actions towards employees in agribusiness enterprises and to assess their impact on the level of economic and social benefits resulting from the use of the CSR concept in business practice. The survey research carried out on a sample of 325 companies from the SME sector conducting business in rural areas of the Mazowieckie Voivodeship served to meet the objective of the paper. The results indicate a positive, strong impact of involvement in the CSR activities on the obtained effects, which is more pronounced in the case of economic benefits than social benefits, and can be observed more clearly in smaller companies. Key socially responsible actions towards employees include employee satisfaction surveys as well as data protection and protection of employee privacy. Activity in the analyzed CSR area mainly translates into financial performance and building a positive image of enterprises in their environment

Keywords: corporate social responsibility, CSR towards employees, rural areas, agribusiness enterprises. 


\section{Streszczenie}

\section{Ekonomiczne i społeczne korzyści działań społecznie odpowiedzialnych na rzecz pracowników w przedsiębiorstwach agrobiznesu}

Celem artykułu jest identyfikacja zakresu działań społecznie odpowiedzialnych na rzecz pracowników w przedsiębiorstwach agrobiznesu oraz ocena ich wpływu na poziom korzyści ekonomicznych i społecznych wynikających $\mathrm{z}$ wykorzystania koncepcji CSR w praktyce gospodarczej. Realizacji celu pracy poświęcono własne badania ankietowe przeprowadzone na próbie 325 firm sektora MSP prowadzących działalność na obszarach wiejskich województwa mazowieckiego. Wyniki wskazują na pozytywny, silny wpływ zaangażowania w działania z zakresu CSR na uzyskiwane efekty, przy czym jest on bardziej wyraźny w przy padkukorzyści ekonomicznych, niżspołecznychiwystępuje raczej w firmach mniejszej wielkości. Do kluczowych działań społecznie odpowiedzialnych na rzecz zatrudnionych można zaliczyć badania satysfakcji oraz ochronę danych i prywatności pracowników. Aktywność w rozpatrywanym obszarze CSR przekłada się przede wszystkim na wyniki finansowe oraz na budowanie pozytywnego wizerunku firm $\mathrm{w}$ otoczeniu.

\section{Słowa}

kluczowe: społeczna odpowiedzialność biznesu, CSR na rzecz pracowników, obszary wiejskie, przedsiębiorstwa agrobiznesu.

JEL

Classification: L26; M14; Q10; J28.

\section{References}

1. Apanowicz, J. (2003). Metodologia nauk. Torun: Wydawnictwo “Dom Organizatora".

2. Buysee, K., \& Verbeke, A. (2003). Proactive environmental strategies: a stakeholder management perspective. Strategic Management Journal, 24(5), 453-475. doi:10.1002/smj.299.

3. Carroll, A. (1974). Corporate Social Responsibility: its managerial impact and implications. Journal of Business Research, 2(1), 75-90. doi:10.1016/ S0148-2963(74)80008-1.

4. Cronbach, L. J., \& Shavelson, R. J. (2004). My current thoughts on coefficient alpha and successor procedures, Educational and Psychological Measurement, 64(3), 391-418. doi:10.1177/0013164404266386. 
5. Finch, W. H., Immekus, J. C., \& French, B. F. (2016). Applied psychometrics using SPSS and AMOS. Charlotte: Information Age Publishing.

6. Garriga, E., \& Melé, D. (2004). Corporate Social Responsibility theories mapping the territory. Journal of Business Ethics, 53(1-2), 51-68. doi:10.1023/ B:BUSI.0000039399.90587.34.

7. Grodzka, D. (2017). Konkurencyjność polskich regionów na tle regionów państw członkowskich UE. Studia BAS, 1(49), 169-202.

8. Hąbek, P., \& Szewczyk, P. (2010). Społeczna odpowiedzialność a zarządzanie jakościa, Gliwice: Wydawnictwo Politechniki Śląskiej.

9. Kapusta, F. (2012). Agrobiznes. Warszawa: Difin.

10. Knecht, D., Jankowska, A., \& Popiołek M. (2009). Rolnictwo istotnym subsystemem agrobiznesu. Zeszyty Naukowe Uniwersytetu Przyrodniczego We Wroctawiu, 572, Biologia i Hodowla Zwierzat, LVIII, 91-103.

11. Lachiewicz, S., \& Matejun, M. (2012). Specyfika zarządzania małymi i średnimi przedsiębiorstwami. In M. Matejun (Ed.), Zarządzanie mata $i$ średnia firma w teorii $i$ w ćwiczeniach (pp. 13-45). Warszawa: Difin.

12. Martin, R. (2002). The virtue matrix, calculating the return on corporate responsibility. Harvard Business Review, 3, 69-75.

13. Nardi, P. M. (2018). Doing survey research: A guide to quantitative methods. Abingdon: Routledge.

14. Popper, K. R. (2014). The logic of scientific discovery. Eastford: Martino Fine Books.

15. Green Paper (2001). Promocja europejskiego projektu dla społecznej odpowiedzialności biznesu. Komisja Europejska, Zielona Księga - wersja ostateczna (final version).

16. PROW 2014-2020 (2016). Program Rozwoju Obszarów Wiejskich na lata 2014-2020, Skrócona wersja programu. Warszawa: Ministerstwo Rolnictwa i Rozwoju Wsi.

17. Ratajczak, M., Wołoszyn, J, \&Stawicka, E. (2012). Społeczna odpowiedzialność matych $i$ średnich przedsiębiorstw agrobiznesu $z$ obszarów wiejskich. Warszawa: Wydawnictwo SGGW.

18. Ratajczak, M. (2013). Działania CSR wobec pracowników na przykładzie przedsiębiorstw agrobiznesu z Warmii i Mazur. Przegląd Organizacji, 12, 14-19.

19. Ratajczak, M. (2016). Knowledge of the concept of corporate social responsibility in agribusiness enterprises (based on the example of the SME sector in Malopolska). Management, 20(1), 337-351. doi:10.1515/ manment-2015-0043.

20. Roome, N. (2009). Company strategies for corporate responsibility and sustainability in an era of fragmented globalization, Challenges and practices, Stockholm.

21. Sethi, P. (1979). Dimensions of Corporate Social Responsibility. Californian Management Review, 17(3), 57-65. doi:10.2307/41162149. 
22. Swift, L., \& Piff, S. (2014). Quantitative methods: for business, management and finance. Hampshire: Palgrave Macmillan.

23. Tavakol, M., \& Dennick, R. (2011). Making sense of Cronbach's alpha. International Journal of Medical Education, 2, 53-55. doi:10.5116/ ijme. $4 \mathrm{dfb} .8 \mathrm{dfd}$

24. Vogel, D. (2005). The market for virtue - the potential and limits of corporate social responsibility. Washington: DC Brookings Institution Press.

25. Waddock, S. (2008). Building a new institutional infrastructure for corporate responsibility. Academy of Management Perspectives, 22(3), 87-107. doi:10.5465/amp.2008.34587997

26. Wojewódzka-Wiewiórska, A. (2015). Identyfikacja wiejskich obszarów problemowych i barier ich rozwoju na przykładzie województwa mazowieckiego. Roczniki Naukowe Ekonomii Rolnictwa i Rozwoju Obszarów Wiejskich, 102(1), 123-132.

27. Żemigała, M. (2007). Społeczna odpowiedzialność przedsiębiorstwa. Budowanie zdrowej, efektywnej organizacji. Kraków: Oficyna Wolters Kluwer. 